\title{
A New Kaempferol Glycoside with Antioxidant Activity from Chenopodium ambrosioides Growing in Egypt
}

\section{MOSAD AHMED GHAREEB ${ }^{1 *}$, AMAL MOHAMED SAAD ${ }^{1}$, ALLIA MAHMOUD ABDOU1, LAILA ABDEL-GHANY REFAHY ${ }^{1}$ and WAFAA SABRY AHMED ${ }^{1,2}$}

\author{
${ }^{1}$ Medicinal Chemistry Department, Theodor Bilharz Research Institute, Kornaish El-Nile, \\ Warrak El-Hadar 12411, Imbaba (P.O. Box 30), Giza, Egypt. \\ ${ }^{2}$ Department of Chemistry, College of Science and Arts, Sajir, Shaqra University, \\ Kingdom of Saudi Arabia. \\ ${ }^{*}$ Corresponding author E-mail: m.ghareeb @tbri.gov.eg
}

http://dx.doi.org/10.13005/ojc/320626

(Received: October 22, 2016; Accepted: December 08, 2016)

\begin{abstract}
The current study aimed to identify the chemical constituents of Chenopodium ambrosioides (Linn.), and the assessment of the in vitro antioxidant activity of the different extracts and pure isolates. Methods: The antioxidant activity was estimated via free radical scavenging and phosphomolybdenum assays. Structure elucidation of pure compounds was achieved via UV, IR, ${ }^{1} \mathrm{H} \&{ }^{13} \mathrm{C}-\mathrm{NMR},{ }^{1} \mathrm{H}-{ }^{1} \mathrm{H}$ COSY, HMQC, and HMBC, spectroscopy. Bioassay-guided fractionation and isolation of the $n$-butanol fraction led to the isolation of a new kaempferol glycoside namely; kaempferol 3-O- $\alpha-L-{ }^{-1} C_{4}$-rhamnosyl-(1"' $\rightarrow 2$ ") $-\beta-D-{ }^{4} C_{1}$-xylopyranoside (1), together with five known compounds identified as; kaempferol 3-O- $\alpha-\mathrm{L}-{ }^{1} \mathrm{C}_{4}$-rhamnopyranoside (afzelin) (2), kaempferol 7-O- $\alpha$-L${ }^{1} \mathrm{C}_{4}$-rhamnopyranoside (3), caffeic acid (4), 1,2-benzopyrone (coumarin) (5), and kaempferol (6). Compound (1) showed in vitro antioxidant activity of $\mathrm{SC}_{50} 12.45 \mu \mathrm{g} / \mathrm{ml}$, compared to ascorbic acid (AA) with $\mathrm{SC}_{50}$ of $7.50 \mu \mathrm{g} / \mathrm{ml}$. It can conclude that the leaves of $C$. ambrosioides can be used as promising natural antioxidant agents.
\end{abstract}

Keywords: Chenopodiaceae; Chenopodium ambrosioides; Kaempferol 3-O- $\alpha-\mathrm{L}^{-1} \mathrm{C}_{4}$-rhamnosyl$(1 " ' \rightarrow 2 ")-\beta-D-{ }^{4} C_{1}$-xylopyranoside; Antioxidant; DPPH; 2D-NMR.

\section{INTRODUCTION}

The genus Chenopodium constituted of approximately 120 species, 45 of which are known to be distributed all over the world, and nine of which are distributed in Egypt ${ }^{1,2}$. Different species belonging to this genus showed numerous pharmacological properties ${ }^{3,4}$. Also, the previous chemical investigations carried out on this genus revealed the presence of flavonoids ${ }^{5-7}$, terpenes ${ }^{8}$, sesquiterpene pygmol ${ }^{9}$, xyloside $^{10}$, coumarins ${ }^{11}$, and essential oils ${ }^{12}$. Chenopodium ambrosioides Linn 
(Family Chenopodiaceae) is native to temperate America $^{13}$. For a long time C. ambrosioides was used traditionally for solving many health problems i.e., inflammation, diabetes, parasites, cough, typhoid, and influenza ${ }^{14,15}$. Reviewing the literature revealed that the different parts of $C$. ambrosioides showed numerous biological activities i.e., antimicrobial ${ }^{16,17}$, cytotoxicity ${ }^{18}$, antioxidant ${ }^{19}$, larvicidal ${ }^{20}$, antidiabetic ${ }^{4}$, antiparasitic ${ }^{21}$, antiviral| ${ }^{22}$, and molluscidal ${ }^{23}$. Moreover, from the phytochemistry point of view $C$. ambrosioides is known to contain secondary metabolites i.e., saponins ${ }^{24}$, terpenoids ${ }^{2,25,26}$, flavonol glycosides ${ }^{27,28}$, flavone glycosides ${ }^{29}$, and chenopodiumamines $\&$ chenopodiumoside ${ }^{30}$. The accumulation of the reactive free radicals in our bodies led to phenomena known as oxidative stress which represent the imbalance between the endogenous antioxidant molecules in our bodies and the extent of such species. Consequently, any excess amounts of such species led to harmful effects, and in such case should be fixed via supplying the human body by external antioxidants agents in the form of nutrients or food additives ${ }^{19}$. Therefore, the aims of our current research work were to evaluate the in vitro antioxidant activity of $C$. ambrosioides leaves growing in Egypt, accompanied by the chromatographic separation and identification of its bioactive pure isolates.

\section{MATERIALS AND METHODS}

\section{Plant materials}

Leaves of Chenopodium ambrosioides Linn (Family Chenopodiaceae) were collected from Giza Governorate, Egypt in February 2015. The plant was identified by Dr. Threase Labib, Consultant of Taxonomy at the Ministry of Agriculture. A voucher specimen (Ca-2015) was kept at the Herbarium of our department.

\section{Chemicals and apparatus}

Melting point (uncorrected) was recorded using SMP3 Stuart Scientific device (UK). Spectral analyses were measured via Varian Mecauy 300 $\mathrm{MHz}$ spectrometer $\left({ }^{1} \mathrm{H}, 300 \&{ }^{13} \mathrm{C}, 75 \mathrm{MHz}\right.$, in DMSOd6). Chemical shifts $(\delta)$ were expressed in ppm and coupling constant $(J)$ in Hertz. The absorbance measurements were recorded using Camspec (Model M550) double beam scanning UV/Vis spectrophotometer. Infrared spectra were determined in Fourier Transform Infrared Spectrometer (FT/IR)-
6100 JASCO. Sephadex LH-20 (Uppsala, Sweden), paper chromatography (PC) was carried out on Whatman No. 1 and No. 3 paper sheets $(57 \times 46$ cm) $\left(\mathrm{S}_{1}, n\right.$-butanol: acetic acid: $\mathrm{H}_{2} \mathrm{O} ; 4: 1: 5$ upper layer \& $S_{2}$, water: acetic acid; 85:15) (Maidstone, England), while thin layer chromatography (TLC) was performed over pre-coated silica plates (GF254, Merck) $\left(\mathrm{S}_{3}, \mathrm{CHCl}_{3}\right.$ : $\left.\mathrm{MeOH}: \mathrm{H}_{2} \mathrm{O} ; 7: 3: 0.5\right)$.

\section{Extraction and fractionation}

The dried leaves $(2.5 \mathrm{Kg})$ of $C$. ambrosioides were extracted via percolation in $70 \%$ methanol $(5$ L) at room temperature $25 \pm 2^{\circ} \mathrm{C}$, and then repeated till complete extraction process. The combined extracts were concentrated via rotatory evaporator at $45^{\circ} \mathrm{C}$, to afford a dark brown residue $(230 \mathrm{~g})$ from $70 \%$ methanol extract, then was dissolved in petroleum ether $\left(60-80^{\circ} \mathrm{C}\right)(2 \mathrm{~L})$ to remove the lipoidal materials i.e., fats and sterols, to afford a semi oily residue $(6.06 \mathrm{~g})$. The defatted $70 \%$ methanol $(210 \mathrm{~g})$ was suspended in distilled water and then successively fractionated with methylene chloride (2 L), ethyl acetate (2.5 L), $n$-butanol (3 L), to afford methylene chloride $(31.89 \mathrm{~g})$, ethyl acetate $(3 \mathrm{~g})$, $n$-butanol $(27 \mathrm{~g})$, and water (126 g) dry fractions. The resulting fractions were chromatographically compared via PC using solvent systems $\left(\mathrm{S}_{1} \& \mathrm{~S}_{2}\right)$, which guide us to select the $n-\mathrm{BuOH}$ fraction for further chromatographic separation.

\section{Antioxidant assays}

\section{Free radical scavenging antioxidant activity} assay

The free radical scavenging antioxidant activity of different fractions and pure compounds was evaluated according to the reported method ${ }^{31}$.

\section{Phosphomolybdenum assay}

The total antioxidant capacity was evaluated by the reported method with some minor modifications ${ }^{32}$.

\section{Statistical analysis}

The antioxidant data were presented as mean \pm standard deviation (S.D.) of triplicates $(n=3)$ using SPSS 13.0 program (SPSS Inc. USA).

\section{Chromatographic isolation of $\boldsymbol{n}$-BuOH fraction}

Twenty five grams of the $n$-butanol fraction were subjected to chromatographic isolation using 
polyamide column chromatography (CC.) $(100 \times 6$ $\mathrm{cm}, 300 \mathrm{gm}$ ). A gradient elution was started with $5 \%$ $\mathrm{MeOH}$ and the polarity was gradually increased by methanol to pure $\mathrm{MeOH}$ at the end. Fractions (250 $\mathrm{ml}$ each) were collected, concentrated and examined (PC, $\mathrm{S}_{1} \& \mathrm{~S}_{2}, 5 \% \mathrm{AlCl}_{3}$ and $1 \% \mathrm{FeCl}_{3}$, UV light for detection). Similar fractions were pooled according to their pattern upon paper chromatography, to afford five main fractions (1-5) matching to the flavonoids \& phenolic category. Fraction $1(3 \mathrm{~g})$ was eluted with $10 \% \mathrm{MeOH}$, and purified over Sephadex LH-20 (CC.) to afford a yellow needles of compound $1(40 \mathrm{mg})$ eluted via $\mathrm{H}_{2} \mathrm{O}: \mathrm{MeOH}$ (40:60). Fraction 2 (2 g) was eluted with $20 \% \mathrm{MeOH}$, and purified over Sephadex $\mathrm{LH}-20$ to afford compound $2(20 \mathrm{mg})$ eluted via $\mathrm{H}_{2} \mathrm{O}$ : $\mathrm{MeOH}(30: 70)$. Fraction $3(3 \mathrm{~g})$ was eluted with $30 \%$ $\mathrm{MeOH}$, and purified over Sephadex LH-20 to afford compound $3\left(25 \mathrm{mg}\right.$ ) were eluted via $\mathrm{H}_{2} \mathrm{O}: \mathrm{MeOH}$ (25:75). Fraction $4(4 \mathrm{~g})$ eluted with $40 \% \mathrm{MeOH}$, was purified over Sephadex LH-20 to afford compound 4 (10 mg) and compound 5 (20 mg) eluted via $\mathrm{H}_{2} \mathrm{O}$ : $\mathrm{MeOH}(20: 80)$ and $\mathrm{H}_{2} \mathrm{O}: \mathrm{MeOH}$ (15:85), Finally, fraction $5(2 \mathrm{~g})$ was eluted with $70 \% \mathrm{MeOH}$, and purified over Sephadex LH-20 to afford compound 6 (15 mg) eluted via $\mathrm{H}_{2} \mathrm{O}: \mathrm{MeOH}$ (10:90).

\section{Complete acid hydrolysis}

The compound ( $3-5 \mathrm{mg}$ ) was refluxed using dilute hydrochloric acid $\mathrm{HCl}$ in $\mathrm{MeOH}$ at $100^{\circ} \mathrm{C}$ for 3 hrs, then the hydrolysate was exhaustively extracted with ethyl acetate in separating funnel. Aglycones identified via Co-PC with authentic aglycone sample. The aqueous phase was neutralized with $5 \%$ sodium bicarbonate and used for investigation of the sugar moieties via Co-TLC with authentic sugar markers ${ }^{33}$

\section{RESULTS AND DISCUSSION}

\section{In vitro antioxidant activities (DPPH, TAC)}

In the current study, the Chenopodium ambrosioides leaves were examined for their antioxidant activities using 2,2' diphenyl1-picrylhydrazyl radical (DPPH.) and Phosphomolybdenum assays. The results in Table 1 revealed that $n$-butanol extract exhibited a potent activity with $\mathrm{SC}_{50}$ value $2.98 \mu \mathrm{g} / \mathrm{ml}$, which nearly twice the value of standard ascorbic acid $7.50 \mu \mathrm{g} / \mathrm{ml}$. While, the ethyl acetate extract exhibited activity with $\mathrm{SC}_{50}$ value $16.48 \mu \mathrm{g} / \mathrm{ml}$, followed by a moderate activity of the $70 \%$ methanol extract with $\mathrm{SC}_{50}$ value $55.33 \mu \mathrm{g} / \mathrm{ml}$, while the remaining teste extracts (petroleum ether and methylene chloride) showed very weak activity $>100 \mu \mathrm{g} /$ $\mathrm{ml}$. Furthermore, in the phosphomolybdenum assay the $n$-butanol extract was also the most potent of TAC $(554.54 \pm 2.27 \mathrm{mg}$ ascorbic acid equivalent/g dry extract), accompanied by ethyl acetate and $70 \% \mathrm{MeOH}$ of TAC $(418.93 \pm 2.62)$, and $(341.66 \pm 1.10)$ respectively, however the weak activity was recorded with the remaining fractions $\mathrm{CH}_{2} \mathrm{Cl}_{2}(159.84 \pm 1.29)$, and pet. ether (118.93 \pm

Table 1: Antioxidant activities of the different fractions of $C$. ambrosioides.

\begin{tabular}{lcc}
\hline Sample & $\begin{array}{c}\text { DPPH free radical } \\
\text { scavenging activity } \\
\text { SC }_{50}(\mu \mathbf{g} / \mathbf{m l})^{1}\end{array}$ & $\begin{array}{c}\text { Total antioxidant capacity } \\
\text { (mg ascorbic acid equivalent } \\
\text { AAE /g dry extract) }\end{array}$ \\
\hline $70 \% \mathrm{MeOH}$ & $55.33 \pm 0.78$ & $341.66 \pm 1.10$ \\
$\mathrm{Pet}$ ether & $>100$ & $118.93 \pm 1.31$ \\
$\mathrm{CH}_{2} \mathrm{Cl}_{2}$ & $>100$ & $159.84 \pm 1.29$ \\
$\mathrm{EtOAC}$ & $16.48 \pm 0.16$ & $418.93 \pm 2.62$ \\
$n$ - $\mathrm{BuOH}$ & $2.98 \pm .011$ & $554.54 \pm 2.27$ \\
Ascorbic acid & $7.50 \pm 0.32$ & \\
\hline
\end{tabular}

${ }^{1} \mathrm{SC}_{50}$ : concentration from sample required for scavenging of $50 \%$ of radical;

${ }^{2}$ Total antioxidant capacity (TAC) was evaluated by the phosphomolybdenum assay in $\mathrm{mg}$ ascorbic acid equivalent $\mathrm{AAE} / \mathrm{g}$ dry extract. 
1.31) $\mathrm{mg}$ ascorbic acid equivalent/g dry extract) (Table 1). The results obtained can serve as a significant indicator for the antioxidant activity of the n-butanol extract which prompted us to subject it for further chromatographic isolation to identify its chemical constituents which may be responsible for such activity. Reviewing the literature revealed, several Chenopodium species were investigated for their in vitro antioxidant activities, i.e., Amri et al. (2015) reported that the antioxidant activity of the $80 \%$ methanol extract of Moroccan Chenopodium ambrosioides equal to $73.80 \%{ }^{34}$. In addition, the $80 \% \mathrm{MeOH}$ of $C$. ambrosioides leaves growing in Egypt showed superoxide anion scavenging activity of $55.78 \%$ and iron chelating activity $73.37 \%{ }^{35}$. Moreover, Barros et al. (2013) reported that the activity of the methanolic extract of Portuguese $C$. ambrosioides in $\mathrm{EC}_{50}$ was equal to $0.62 \mathrm{mg} / \mathrm{ml}^{19}$. Further more, the activity of the methanolic extract of C. ambrosioides growing in Yemen was 31.9\% at 100 $\mathrm{mg} / \mathrm{ml}^{36}$. Actually, no reports are accessible on the total antioxidant capacity of the $C$. ambrosioides.

\section{Identification and characterization of the isolated metabolites}

In the current study, the chromatographic isolation and purification of the $n$-butanol fraction of $C$. ambrosioides resulted in the separation of six compounds (Fig. 1, 2). The new compound was identified on the basis of 1D \& 2D-NMR as; kaempferol 3-O- $\alpha-$ L- $^{-1} \mathrm{C}_{4}$-rhamnosyl-(1"' $\rightarrow 2$ ") $-\beta$ $\mathrm{D}-{ }^{4} \mathrm{C}_{1}$-xylopyranoside(1), as well as five known compounds were identified as; kaempferol 3-O- $\alpha$ $\mathrm{L}-^{1} \mathrm{C}_{4}$-rhamnopyranoside (afzelin)(2), kaempferol 7-O- $\alpha-\mathrm{L}-{ }^{1} \mathrm{C}_{4}-$ rhamnopyranoside(3), caffeic acid(4), 1,2-benzopyrone (coumarin)(5) and kaempferol(6).

\section{Structural elucidation}

Compound (1): Was obtained as a yellow needles, mp $208-210^{\circ} \mathrm{C}$, Rf-values 0.56 in $\left(S_{1}\right)$,<smiles>[R]Oc1cc(O)c2c(=O)c(O[R1])c(-c3ccc(O)cc3)oc2c1</smiles>

$\mathbf{R}_{1}=$ Rha-Xyl, $\mathbf{R}_{2}=\mathrm{H}$ : kaempferol 3-O- $\alpha-\mathrm{L}-{ }^{1} \mathrm{C}_{4}$-rhamnosyl-(1'"' $\left.\rightarrow \mathbf{2}^{\prime \prime}\right)-\beta-\mathrm{D}-{ }^{-4} \mathrm{C}_{1}$-xylopyranoside(1)

$\mathbf{R}_{1}=\mathbf{R h a}, \mathbf{R}_{2}=\mathrm{H}$ : kaempferol 3-O- $\alpha-\mathrm{L}-{ }^{1} \mathrm{C}_{4}-$ rhamnopyranoside (afzelin)(2)

$\mathbf{R}_{1}=\mathbf{H}, \mathbf{R}_{2}=$ Rha: kaempferol 7-O- $\alpha-\mathrm{L}^{-1} \mathrm{C}_{4}-$ rhamnopyranoside(3)

$\mathbf{R}_{1}=\mathbf{R}_{2}=\mathbf{H}$ : kaempferol $(6)$<smiles>O=C(O)/C=C/c1ccc(O)c(O)c1</smiles><smiles></smiles>

Fig.1. Chemical structures of phenolic compounds isolated from C. ambrosioides 
and 0.75 in $\left(\mathrm{S}_{2}\right) . \cup V \lambda_{\max } \mathrm{nm}: \mathrm{MeOH} 267,301,356$; $+\mathrm{NaOMe} 275,336^{\text {sh }}, 400 ;+\mathrm{AlCl}_{3} 275,305^{\text {sh }}, 356$, $412 ;+\mathrm{AlCl}_{3} \pm \mathrm{HCl} 278,302^{\text {sh }}, 349^{\text {sh }}, 409 ;+\mathrm{NaOAC}$ $274,314^{\text {sh }}, 396 ;+\mathrm{NaOAc} \pm \mathrm{H}_{3} \mathrm{BO}_{3} 271,308^{\text {sh }}, 362$ $\mathrm{nm}$. Acid hydrolysis of 1 gave xylose \& rhamnose in the aqueous phase and kaempferol in the organic phase (Co-PC). ${ }^{1}$ HNMR of the aglycone showed two characteristic spin coupling systems, each of two doublets in the aromatic region, for 4'-hydroxy B-ring and 5, 7-dihydroxy A-ring of a kaempferol moiety. The $1^{\text {st }}$ system was described as $A X$ of two ortho doublets at $\delta 7.80$ and 6.90 ppm for H-2'/6' and $\mathrm{H}-3^{\prime} / 5$ ', respectively, while the $2^{\text {nd }}$ system was of two meta doublets at 6.78 and $6.45 \mathrm{ppm}$ of $\mathrm{H}-8$ and $\mathrm{H}-6$, respectively. ${ }^{1} \mathrm{HNMR}$ also showed a $\beta$-anomeric proton signal of inner xyloside moiety at $\delta 5.38 \mathrm{ppm}$ and $\mathrm{CH}_{3}-6$ '” as doublet at $1.11 \mathrm{ppm}$ of terminal rhamnosyl moiety. Two anomeric proton signals were assigned at $\delta 5.38$ (xyloside) and 5.15 (rhamnoside) ppm, in the ${ }^{1}$ HNMR spectrum through their direct one bond coupling in the HMQC spectrum with their own anomeric carbon signals at 101.5 and $102.0 \mathrm{ppm}$, respectively (Table 2). The 3-O-subistituted kaempferol moiety was confirmed from its characteristic 13 resonances in the ${ }^{13} \mathrm{CNMR}$ spectrum as it was interpreted above,

Table 2: ${ }^{1} \mathrm{H} \&{ }^{13} \mathrm{C}$ NMR spectral data (300/75 MHz-DMSO- $\left.d_{6}\right),{ }^{1} \mathrm{H}-{ }^{-1} \mathrm{H}$ COSY and HMBC assignments of compound 1

\begin{tabular}{|c|c|c|c|c|c|}
\hline Position & $\delta_{\mathrm{H}} \mathrm{ppm}^{1}$ & $J(\mathrm{~Hz})^{2}$ & $\begin{array}{l}{ }^{1} \mathrm{H}-+\mathrm{H} \text { COSY } \\
\text { correlations }\end{array}$ & $\delta_{\mathrm{c}} \mathrm{ppm}$ & $\begin{array}{l}\mathrm{HMBC}(\mathrm{H}-\mathrm{C}) \\
\text { correlations }\end{array}$ \\
\hline 2 & & & & $157.8(q)$ & \\
\hline 3 & & & & $134.7(q)$ & \\
\hline 4 & & & & $178.0(q)$ & \\
\hline 5 & & & & $158.0(q)$ & \\
\hline 6 & 6.45 & $1 \mathrm{H}, \mathrm{d}, 1.8$ & & $98.6(t)$ & \\
\hline 7 & & & & $161.9(q)$ & \\
\hline 8 & 6.78 & $1 \mathrm{H}, \mathrm{d}, 1.8$ & & $94.7(\mathrm{t})$ & \\
\hline 9 & & & & $156.2(q)$ & \\
\hline 10 & & & & $105.9(q)$ & \\
\hline $1^{\prime}$ & & & & $120.4(q)$ & \\
\hline $2^{\prime}$ & 7.80 & $\mathrm{dd}, 7.2,1.8$ & & $130.8(t)$ & \\
\hline $3^{\prime}$ & 6.90 & $1 \mathrm{H}, \mathrm{d}, 8.7$ & & $115.4(\mathrm{t})$ & \\
\hline $4^{\prime}$ & & & & $160.6(q)$ & \\
\hline $5^{\prime}$ & 6.90 & $1 \mathrm{H}, \mathrm{d}, 8.7$ & & $115.4(\mathrm{t})$ & \\
\hline $6^{\prime}$ & 7.80 & $\mathrm{dd}, 7.2,1.8$ & & $130.8(\mathrm{t})$ & \\
\hline $1^{\prime \prime}$ & 5.38 & & $2^{\prime \prime}$ & $101.5(\mathrm{t})$ & 3", 3 \\
\hline $2^{\prime \prime}$ & & & 3", 2" & $79.2(t)$ & $4^{\prime \prime}$ \\
\hline $3^{\prime \prime}$ & & & 4", 2" & $76.4(t)$ & $1^{\prime \prime}, 5^{\prime \prime}$ \\
\hline $4^{\prime \prime}$ & & & 5", 3" & $70.0(\mathrm{t})$ & $6^{\prime \prime}, 2^{\prime \prime}$ \\
\hline $5^{\prime \prime}$ & & & 6", 4" & $65.9(\mathrm{~s})$ & $3^{\prime \prime}$ \\
\hline $6^{\prime \prime}$ & & & $5^{\prime \prime}$ & & $4 "$ \\
\hline $1^{\prime \prime \prime}$ & 5.15 & & $2^{\prime \prime \prime}$ & $102.0(\mathrm{t})$ & $2^{\prime \prime}, 3^{\prime \prime \prime}$ \\
\hline $2^{\prime \prime \prime}$ & & & $3^{\prime \prime \prime}, 1^{\prime \prime \prime}$ & $70.8(\mathrm{t})$ & $4 " 1$ \\
\hline $3^{\prime \prime \prime}$ & & & $4^{\prime \prime \prime}, 2^{\prime \prime \prime}$ & $70.5(t)$ & $1^{\prime \prime \prime}, 5^{\prime \prime \prime}$ \\
\hline $4^{\prime \prime \prime}$ & & & $5^{\prime \prime \prime}, 3^{\prime \prime \prime}$ & $73.9(\mathrm{t})$ & $2^{\prime \prime \prime}, 6^{\prime \prime \prime}$ \\
\hline $5^{\prime \prime \prime}$ & & & $6^{\prime \prime \prime}, 4^{\prime \prime \prime}$ & $69.5(\mathrm{t})$ & $3^{\prime \prime \prime}$ \\
\hline $6^{\prime \prime \prime}$ & 1.11 & $3 \mathrm{H}, \mathrm{d}, 6.3$ & $5^{\prime \prime \prime}$ & $18.0(p)$ & $4^{\prime \prime \prime}$ \\
\hline
\end{tabular}

${ }^{1} \mathrm{H}$ : Chemical shifts $\delta$ in (ppm).

${ }^{2}$ Coupling constants $J$ in $(\mathrm{Hz})$. 
specially signals at 130.8 and $115.4 \mathrm{ppm}$ of C-2'/6' and 3'/5' intrinsic for 1,4-disubstituted B-ring of kaempferol aglycone. Glycosidation at $\mathrm{OH}-3$ was proved by the relative upfield shift of $\mathrm{C}-3$ to 134.7 ( $\Delta \approx-3-4 \mathrm{ppm})$ and downfield shift of C-2 at 156.2 $\mathrm{ppm}$. The connectivity of the xyloside moiety to C-3 of the aglycone was further proved by the correlation peak of $\mathrm{H}-1$ " ( $\delta 5.38)$ and C-3 ( $\delta 134.7$ ppm) in HMBC spectrum. Similarly the downfield shift of C-2" (79.2 ppm) explained the attachment of the rhamnosyl moiety at C-2" of xylose. The interglycosidic linkage was also assigned as (1"' $\rightarrow 2$ ") on the basis of the three bond correlation peak between $\mathrm{H}-1$ '” $(\delta 5.15$ ppm) and C-2" ( $\delta 79.2$ ppm) in the HMBC spectrum. The sugar moieties were deduced to have $\beta-{ }^{4} \mathrm{C}_{1}-$, or $\alpha-{ }^{-1} C_{4}$-pyranose stereo structure in the case of the xylosyl and rhamnosyl moieties, respectively, on the basis of the $J$-values of the anomeric protons and $\delta$-values of their ${ }^{13} \mathrm{CNMR}$ resonances (Table 2). All other ${ }^{1} \mathrm{H}$ and ${ }^{13} \mathrm{C}$ resonances were also confirmed by the ${ }^{1} \mathrm{H}-{ }^{1} \mathrm{H}-\mathrm{COSY}, \mathrm{HMQC}$ and HMBC spectra and by comparison with previously reported data for structurally related compounds ${ }^{7}$. Thus, compound 1 was identified as kaempferol 3-O$\alpha-L-{ }^{-1} C_{4}$-rhamnosyl-(1'"' $\rightarrow 2$ ") $-\beta-D-{ }^{4} C_{1}$-xylopyranoside (Fig. 1, 2).

Compound (2): Was obtained as pale yellow powder, $\mathrm{mp} 181-183^{\circ} \mathrm{C}$. Rf-values 0.69 in $\left(\mathrm{S}_{1}\right)$, and 0.58 in $\left(\mathrm{S}_{2}\right)$. IR $\left(\mathrm{KBr} \mathrm{cm}^{-1}\right)$ : showed peaks at 3350, 1658, 1609, 1510, 1456, 1369, 1308, 1028, 823 $\mathrm{cm}^{-1}$. It showed similar chromatographic behavior, chemical and NMR spectral data to kaempferol except for the NMR spectral data assignable to the sugar moiety. Acid hydrolysis of compound 2 afforded rhamnose in the aqueous phase and kaempferol in the organic phase. The ${ }^{1} \mathrm{HNMR}$ at $\delta 5.54$ (assignable to $\alpha$-anomeric protons as brs) and at 1.05 (for $\mathrm{CH}_{3}-6$ ") were characteristic for $\alpha$-L-rhamnopyranosyl moiety at $\mathrm{OH}-3$. Compound 6 showed $\operatorname{six}{ }^{13} \mathrm{C}$ - resonances of O-rhamnopyranoside moiety among which C-4", C-3", C-2" and C-5" of $\delta$-values around 70 ppm and $\mathrm{CH} 3-6$ " as the most upfield signal at $17.4 \mathrm{ppm}$. Glycosidation at $\mathrm{OH}-3$ was proved by the relative upfield shift of C-3 to 134.9 ( $\Delta \approx-3-4 \mathrm{ppm})$ and downfield shift of $\mathrm{C}-2$ at $157.7 \mathrm{ppm}$. Assignment of all other ${ }^{13} \mathrm{C}$ resonances was proved by their comparison with the reported data in the literature ${ }^{37}$. Hence compound 6 was identified as kaempferol 3-O- $\alpha-L-{ }^{-1} \mathrm{C}_{4}$-rhamnopyranoside (afzelin) (Fig. 1).

Compound (3): Was obtained as a yellow powder, mp $171-172^{\circ} \mathrm{C}$. Rf-values 0.64 in $\left(\mathrm{S}_{1}\right)$, and 0.55 in $\left(\mathrm{S}_{2}\right)$. IR $\left(\mathrm{KBr} \mathrm{cm}^{-1}\right)$ : showed peaks at $3340,1655,1620,1515,1465,1350,1025,830$ $\mathrm{cm}^{-1}$. The aglycone moiety showed very similar chromatographic behavior, chemical and NMR spectral data to kaempferol aglycone. Acid hydrolysis of compound 3 afforded rhamnose in the aqueous phase and kaempferol in the organic phase. NMR spectral data of 3 resembled that of compound 2 (afzelin) for aglycone and sugar moiety. However in compound 3 the rhamnose moiety attached to C-7 instead of C-3 in compound 2, which confirmed

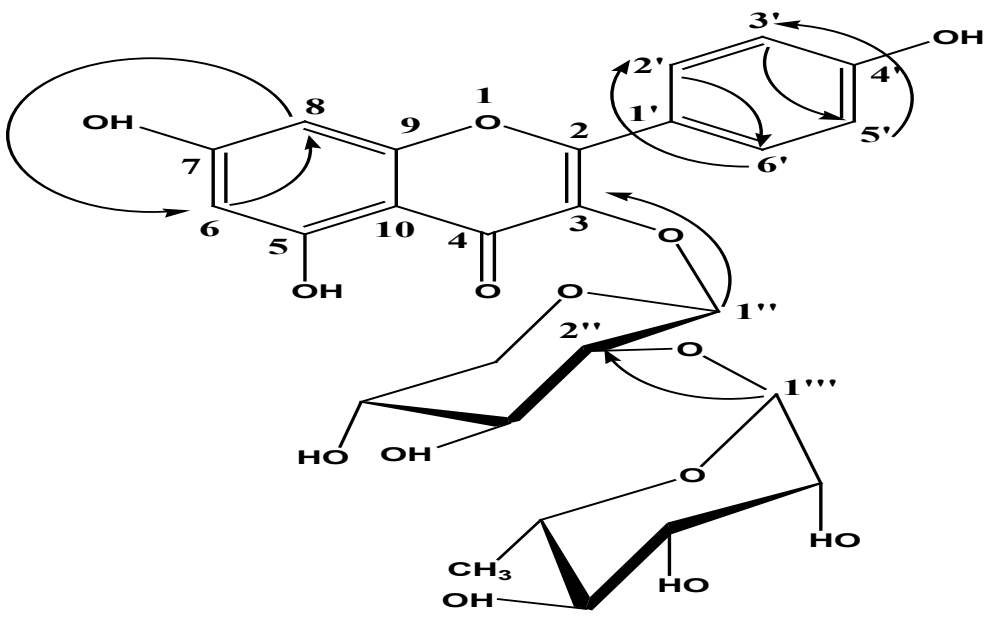

Arrows pointed from $\mathrm{H} \longrightarrow \mathrm{C}$

Fig. 2: Selected HMBC correlations of compound 1 
from the downfield shift of both $\mathrm{H}-8$ and $\mathrm{H}-6$ to 6.4 and $6.10 \mathrm{ppm}$, respectively. All other NMR resonances assigned through a comparison study with the previously published data ${ }^{38}$. Therefore compound 3 was identified as kaempferol $7-O-\alpha-\mathrm{L}-$ ${ }^{1} \mathrm{C}_{4}$-rhamnopyranoside (Fig.1).

Compound (4): Was obtained as a pale yellow amorphous solid, $\mathrm{mp} 225-227^{\circ} \mathrm{C}$, Rf-values 0.54 in $\left(\mathrm{S}_{2}\right)$, and 0.63 in $\left(\mathrm{S}_{3}\right)$. It showed bluish-grey colour with $\mathrm{FeCl}_{3}$ and blue under long UV light. IR $\left(\mathrm{KBr} \mathrm{cm}^{-1}\right)$ : showed peaks at 3430 (Ar-ring, $\mathrm{OH}$ ), 3235 (Ar-ring, -C-H), 2915 (aliphatic-C-H), $1650(-\mathrm{C}=\mathrm{O})$, $1625(-\mathrm{C}=\mathrm{C}), 1619,1520$ and 1449 (Ar-ring, $-\mathrm{C}=\mathrm{C}$ ), 1250 and 1296 (ether bond of carboxylic group), and $1193 \mathrm{~cm}^{-1}$ (hydroxy bond of carboxylic group). ${ }^{1} \mathrm{HNMR}$ spectra (300 MHz, DMSO-d6) showed the existence of three characteristic signals of aromatic moiety (ABX system) at $\delta 7.01\left({ }^{1} \mathrm{H}, \mathrm{d}, \mathrm{J}=2.1 \mathrm{~Hz}, \mathrm{H}-2\right)$, $6.96(1 \mathrm{H}, \mathrm{dd}, \mathrm{J}=8.1,2.1 \mathrm{~Hz}, \mathrm{H}-6), 6.76(1 \mathrm{H}, \mathrm{d}, \mathrm{J}=8.1$ $\mathrm{Hz}, \mathrm{H}-5)$, \& two signals for cinnamoeyl moiety 7.42 $(1 \mathrm{H}, \mathrm{d}, J=15.9 \mathrm{~Hz}, \mathrm{H}-7)$, and $6.18(1 \mathrm{H}, \mathrm{d}, J=15.9$ $\mathrm{Hz}, \mathrm{H}-8) \mathrm{ppm}$. The mentioned data of compound 4 were matched with the previous reported data of 3-(3,4-dihydroxyhenyl)-2-propenoic acid (caffeic acid) ${ }^{39}$ (Fig.1).

Compound (5): Was obtained as a white fine crystal, m.p. $70-72^{\circ} \mathrm{C}$. ${ }^{1} \mathrm{HNMR}(300 \mathrm{MHz}$, DMSOd6) revealed the presence of a characteristic signals at $\delta 6.47(1 \mathrm{H}, \mathrm{d}, J=9.6 \mathrm{~Hz}, \mathrm{H}-3), 8.03(1 \mathrm{H}, \mathrm{d}, J=9.9$ $\mathrm{Hz}, \mathrm{H}-4), 7.29(2 \mathrm{H}, \mathrm{m}, \mathrm{H}-5,7), 7.58(2 \mathrm{H}, \mathrm{m}, \mathrm{H}-6,8)$ ppm40. ${ }^{13} \mathrm{CNMR}$ (75 MHz, DMSO-d6) revealed the existence of nine signals of 9 carbon atoms assigned to; C-2 (159.84), C-3 (116.18), C-4 (144.10), C-5 (128.35), C-6 (124.38), C-7 (131.84), C-8 (116.11), C-9 (153.43), and C-10 (118.6) ppm. These spectral data were found to be in full agreement with the previous reports, therefore the compound 5 can be characterized as 1,2-benzopyrone (coumarin) ${ }^{41}$ (Fig.1).

Compound (6): Was obtained as a yellow fine crystals, $\mathrm{mp} 280-282^{\circ} \mathrm{C}$, Rf-values 0.84 in $\left(\mathrm{S}_{1}\right)$, and 0.38 in $\left(\mathrm{S}_{2}\right)$. UV $\lambda_{\max } \mathrm{nm}: \mathrm{MeOH} 264,372$; $+\mathrm{NaOMe} 263,284,358 \mathrm{sh}, 452 ;+\mathrm{AlCl}_{3} 262,302^{\text {sh }}$, 363,$425 ;+\mathrm{AlCl}_{3} \pm \mathrm{HCl} 262,301^{\text {sh }}, 345^{\text {sh }}, 426 ;+$ $\mathrm{NaOAc} 263,323^{\text {sh }}, 385 ;+\mathrm{NaOAc} \pm \mathrm{H}_{3} \mathrm{BO}_{3} 258,315^{\text {sh }}$, 368. IR spectrum $\left(\mathrm{KBr} \mathrm{cm}^{-1}\right)$ : showed absorption peaks at 3425 (hydroxyl), 1695 (4-oxo carbonyl), and 1650 (aromatic double bond) $\mathrm{cm}^{-1}$. Based on its chromatographic behavior and UV data compound 6 was likely to be kaempferol like skeleton. In the aromatic region there are two spin coupling systems, each of two doublets. The first one consists of two ortho doublets at 8.02 and $6.92 \mathrm{ppm}$ allocated to $\mathrm{H}-2^{\prime} / 6^{\prime}$ and $\mathrm{H}-3{ }^{\prime} / 5$ ' both of $\mathrm{J}=7.5 \mathrm{~Hz}$, respectively of 4'-hydroxy B-ring. Whereas the second system appeared as two meta-coupled protons, which were characterized to $\mathrm{H}-8$ and $\mathrm{H}-6$ of 5,7-dihydroxy A-ring at $\delta 6.42$ and $6.17 \mathrm{ppm}$ both of $J=1.5 \mathrm{~Hz}$, respectively. ${ }^{13} \mathrm{CNMR}$ spectrum exhibited typical 13 ${ }^{13} \mathrm{C}$-resonances for kaempferol ${ }^{42}$. Based on these findings compound 6 was identified as 3,5,7,4'-tetra hydroxyl flavone (kaempferol) (Fig.1).

\section{In vitro antioxidant activity of the isolated compounds (1-6)}

The antioxidant activities of the compounds

(1-6) were evaluated using free radical scavenging assay. Compound 4 exhibited potent antioxidant activity of $\mathrm{SC}_{50} 4.20 \mu \mathrm{g} / \mathrm{ml}$, followed by compound 6 of $\mathrm{SC}_{50} 6.35 \mu \mathrm{g} / \mathrm{ml}$, while the remaining compounds $1,2,3$, and 5 showed moderate antioxidant activities of $\mathrm{SC}_{50} 9.41,12.45,9.20$, and $10.84 \mu \mathrm{g} / \mathrm{ml}$ separately, with respect to ascorbic acid of $\mathrm{SC}_{50} 7.50 \mu \mathrm{g} / \mathrm{ml}$. The high antioxidant activity of 4 and 6 may be return to the presence of the characteristic structural criteria for effective free radical scavenging activity including; the presence of cinnamoeyl moiety and ortho dihydroxy groups in case of compound 4, and also the presence of an 2, 3 unsaturated double bond, 4-oxo group (ring-C), and 5-OH (A-ring), in case of compound 643. Moreover, mono and di kaempferol glycosides 1 and 2 were less active than their aglycone 6 , which may be due to steric hindrance offered by a bulky glycosidic moiety at position 3 (ring-C). On the other hand the slightly high activity of 3 than 1 and 2 due to the location of the glycosidic moiety in position 7 at ring- $A$ which not affected on the conjugation process between ring-B and 2,3 D.B. \& 4-carbonyl group of the aromatic $\mathrm{C}$-ring ${ }^{44}$.

\section{CONCLUSION}

The current study demonstrated that $\mathrm{n}$-butanol extract had the highest in vitro antioxidant activity among all tested extracts from methanolic extract $C$. ambrosioides. Moreover, the chromatographic isolation and purification of 
the most promising $n$-butanol extract resulted in the separation of one new compound identified as kaempferol 3-O- $\alpha-\mathrm{L}-{ }^{1} \mathrm{C}_{4}$-rhamnosyl-(1"' $\rightarrow 2$ ")$\beta-D-{ }^{4} C_{1}$-xylopyranoside (1), along with five known compounds viz., kaempferol 3-O- $\alpha-\mathrm{L}-$
${ }^{1} \mathrm{C}_{4}$-rhamnopyranoside (afzelin) (2), kaempferol 7-O- $\alpha$-L- ${ }^{-1} \mathrm{C}_{4}$-rhamnopyranoside (3), caffeic acid (4), 1,2-benzopyrone (coumarin) (5), and kaempferol (6). It can conclude that the leaves of the Egyptian C. ambrosioides can be used as promising natural antioxidant agents.

\section{REFERENCES}

1. Takholm, V. In Students Flora of Egypt. Cairo University, Anglo-Egyptian Book Shop: Cairo, 1977; 107.

2. Ahmed, A.A. J. Nat. Prod. 2000, 63, 989991.

3. Koba, K.; Catherine, G.; Raynaud, C.; Chaumont, J.; Sanda, K.; Laurence, N. Bangladesh J. Sci. Ind. Res. 2009, 44, 435440.

4. Song, M.; Lee, S.; Kim, D. Phytopharmacology 2011, 1, 12-15.

5. Pascual, J.; Gonzalez, M.S.; Vicente, S.; Bellido, I.S. Planta Med. 1981, 41, 389-391.

6. Simone, F.D.; Dini, A.; Pizza, C.; Saturnino, P.; Schettino, O. Phytochemistry 1990, 29, 369-3692.

7. Gohar, A.A.; Maatooq, G.T.; Niwa, M. Phytochemistry 2000, 53, 299-303.

8. Mata, R.; Navarrete, A.; Alvarez, L.; PeredaMiranda, R.; Delgado, G.; Vivar, A.R.D. Phytochemistry 1987, 26, 191-193.

9. Bergeron, C., Marston, A.; Hakizamungu, E.; Hostettmann, K. Int. J. Pharm. 1995, 33, 115-1 19.

10. Dellagreca, M.; Previtera, L.; Zarrelli, A. Nat. Prod. Res. 2005, 19, 87-90.

11. El-Sayed, N.H.; Awaad, A.S.; Hifnawy, M.S.; Mabry, T.J. Phytochemistry 1999, 51, 591593.

12. Chekem, M.S.G.; Lunga, P.K.; Tamokou, J.D.D.; Kuiate, J.R.; Tane, P.; Vilarem, G.; Cerny, M. Pharmaceuticals 2010, 3, 29002909.

13. Jia-liang, W.; Dan-wei, M.; Ya-nan, W.; Hong, Z.; Bing, H.; Qun, L.; Zhi-yan, Z.; Jing, F. Trop. J. Pharm. Res. 2013, 12, 929-933.

14. Ruffa, M.; Ferraro, G.; Wagner, M.; Calcagno, M.; Campos, R.; Cavallaro, L.; J. Ethnopharmacol. 2002, 79, 335-339.

15. Yadav, N.; Vasudeva, N.; Singh, S.; Sharma,
S. Nat. Prod. Radiance. 2007, 6, 131-134.

16. Jardim, C.M.; Jham, G.N.; Dhingra, O.; Freire, M.M. J. Braz. Chem. Soc. 2010, 21, 18141818.

17. Shah, H.; Nisar, M.; Suhail, M.; Bacha, N. Afr. J. Microbiol. Res. 2014, 8, 2099-2104.

18. Sousa, Z.; de Oliveira, F.F.; da Conceição, A.O.; Silva, L.A.M.; Rossi, M.H.; Santos, J.S.; Andrioli, J.L. Ann. Clin. Microbiol. Antimicrob. 2012, 11, 1-7.

19. Barros, L.; Pereira, E.; Calhelha, R.C.; Dueñas, M.; Carvalho, A.M.; Santos-Buelga, C.; Ferreira, I.C.F.R. J. Funct. Foods. 2013, 5, 1732-1740.

20. Denloye, A.A.; Makanjuola, W.A.; Teslim, O.K.; Alafia, O.A.; Kasali, A.A.; Eshilokun, A.O. J. Plant Prot. Res. 2010, 50, 379-384.

21. Salifou, S.; Daga, D.F.; Attindéhou, S.; Déguénon, R.; Biaou, C.F. J. Parasitol. Vector Biol. 2012, 5, 13-16.

22. Verma, H.K.; Baranwal, V.K. Natl. Acad. Sci. 1983, 92, 461-465.

23. Hmamouchi, M.; Lahlou, M.; Agoumi, A. Fitoterapia 2000, 71, 308-314.

24. Gupta, G.S.; Behari, M. J. Indian Chem. Soc. 1972, 49, 317-319.

25. Pare, P.W.; Zajicek, J.; Ferracini, V.L.; Melo, I.S. ýBiochem. Syst. Ecol. 1993, 21, 649-653.

26. Kiuchi, F.; Itano, Y.; Uchiyama, N.; Honda, G.; Tsubouchi, A.; Nakajima-Shimada, J.; Aoki, T. J. Nat. Prod. 2002, 65, 509-512.

27. Gohar, A.A.; Elmazar, M.M.A. Phytother. Res. 1997, 11, 564-567.

28. Jain, N.; Alam, M.S.; Kamil, M.; Ilyas, M.; Niwa, M.; Sakae, A. Phytochemistry 1990, 29, 39883991.

29. Hammoda, H.M.; Harraz, F.M.; El Ghazouly, M.G.; Radwan, M.M.; ElSohly, M.A.; Wanas, A.S.; Bassam, S.M. Rec. Nat. Prod. 2015, 9, 609-613. 
30. Song, K.; Zhang, J.; Zhang, P.; Wang, H.; Liu, C.; Li, B.; Kang, J.; Chen, R. J. Asian Nat. Prod. Res. 2015, 17, 1-9.

31. Shirwaikar, A.; Rajendran, K.; Punithaa, I.S. Biol. Pharm. Bull. 2006, 29, 1906-1910.

32. Prieto, P.; Pineda, M.; Aguilar, M. Anal. Biochem. 1999, 269, 337-341.

33. Ghareeb, M.A.; Shoeb, H.A.; Madkour, H.M.F.; Refahy, L.A.; Mohamed, M.A.; Saad, A.M.; Global J. Pharm. 2013, 7, 486-497, 2013.

34. Amri, O.; Elguiche, R.; Tahrouch, S.; Zekhnini, A.; Hatimi, A. J. Chem. Pharm. Res. 2015, 7, 672-678.

35. AbouZid, S.; Elshahaat, A.; Ali, S.; Choudhary, M.I. Drug Discov. Ther. 2008, 2, 286-288.

36. Mothana, R.A.A.; Gruenert, R.; Bednarski, P.J.; Lindequist, U. Pharmazie 2009, 64, 260268.
37. Lee, S.Y.; So, Y.; Shin, M.S.; Cho, J.Y.; Lee, J. Molecules 2014, 19, 3173-3180.

38. Chen, C.; Hsieh, S.; Hsieh, M.; Hsieh, S.; Hsieh, T. Chin. Pharm. J. 2004, 56, 141-146.

39. Jeong, C.; Jeong, H.R.; Choi, G.N.; Kim, D.; Lee, U.; Heo, H.J. Chin. Med. 2011, 6, 1-9.

40. Moreira, M.D.; Picanço, M.C.; Barbosa, L.C.A.; Guedes, R.N.C.; de Campos, M.R.; Silva, G.A.; Martins, J.C. Pesq. Agropec. Bras. Brasilia. 2007, 42, 909-915.

41. Luz, R.F.; Vieira, I.J.C.; Braz-Filho, R.; Moreira, V.F. Am. J. Analyt. Chem. 2015, 6, 851-866.

42. Wan, C.; Yu, Y.; Zhou, S.; Shuge, T.; Cao, S. Pharmacogn. Mag. 2011, 7, 10-108.

43. Rice-Evans, C.A.; Miller, N.J.; Paganga, G. Free Radic. Biol. Sci. 1996, 20, 933-956.

44. Ghareeb, M.A.; Shoeb, H.A.; Madkour, H.M.F.; Refahy, L.A.; Mohamed, M.A.; Saad, A.M. Global J. Pharm. 2014, 8, 87-97. 